\title{
Auto-immune Addison's disease in identical twins
}

\author{
J. P. SIMMONDS* \\ M.R.C.P.
}

\author{
J. LISTER \\ M.D., F.R.C.P.
}

King Edward VII Hospital, Windsor

\begin{abstract}
Summary
Identical male twins are described, one of whom presented with clinical symptoms of Addison's disease whereas the other was shown to have a deficient adrenal cortical response to stimulation tests. Both had positive adrenal cortex antibodies.
\end{abstract}

\section{Case reports}

Twin A, aged 28 years, was admitted as an emergency, complaining of anorexia, weight loss, increased thirst and generalized weakness. These symptoms had been getting progressively worse over the past 2 months, and for the previous week, he had also felt nauseated, had diarrhoea several times a day and was dizzy on standing. On direct questioning, he admitted to not having felt completely well for at least 1 year, but there were no other illnesses in the past.

On examination, there was diffuse brown pigmentation of the whole body, and muscle power was generally reduced. His blood pressure in the lying position was $90 / 60 \mathrm{mmHg}$ and was unrecordable on standing.

\section{Investigations on twin $A$}

$\mathrm{Hb} 15.7 \mathrm{~g} / \mathrm{dl}$; white cell count $6.3 \times 10^{9} / 1$, ESR (Westergren) $3 \mathrm{~mm}$ in $1 \mathrm{hr}$.

Blood acid base: standard bicarbonate $25 \mathrm{mmol} / \mathrm{l}$, glucose $5 \mathrm{mmol} / 1$. Plasma: sodium $118 \mathrm{mmol} / \mathrm{l}$, potassium $5.6 \mathrm{mmol} / \mathrm{l}$, chloride $83 \mathrm{mmol} / \mathrm{l}$, urea $14 \mathrm{mmol} / \mathrm{l}$, phosphate and T4 normal. Serum: calcium normal.

Chest X-ray normal, abdominal X-ray normal with no adrenal calcification. Synacthen test - basal cortisol $=130 \mathrm{mmol} / \mathrm{l}$; cortisol after Synacthen $(250 \mu \mathrm{g})=150 \mathrm{mmol} / 1$ (normal increment $>190$ $\mathrm{mmol} / \mathrm{l}$.

\footnotetext{
* Present address: The Leicester Royal Infirmary,
}

Antibody screen (see Table 1).

A diagnosis of Addison's disease was made and he was treated with replacement therapy of cortisone acetate, $37.5 \mathrm{mg} /$ day and fludrocortisone $0.1 \mathrm{mg} /$ day, with immediate improvement in his symptoms. Subsequently he regained his normal weight and has remained well on this therapy.

Twin B was an identical twin, confirmed by detailed blood group typing (see Table 2). He hado had no previous illnesses, was appreciably heaviers than his twin, was not pigmented and his blood pressure was $120 / 80 \mathrm{mmHg}$.

\section{Investigations on twin $B$}

$\mathrm{Hb} 15.7 \mathrm{~g} / \mathrm{dl}$; white cell count $5.7 \times 10^{9} / 1$, ESR (Westergren) $2 \mathrm{~mm}$ in $1 \mathrm{hr}$.

Blood acid base: standard bicarbonate $29 \mathrm{mmol} / 1$. Plasma: sodium $140 \mathrm{mmol} / \mathrm{l}$, potassium $4.7 \mathrm{mmol} / 1$, urea $4.5 \mathrm{mmol} / 1$, phosphate and T4 normal. Serum: calcium normal.

Chest and abdominal X-rays, normal. Short Synacthen test $(250 \mu \mathrm{g})$ - basal cortisol $420 \mathrm{mmol} / \mathrm{l}$; cortisol after Synacthen $525 \mathrm{mmol} / \mathrm{l}$ (normal increment $>190 \mathrm{mmol} / \mathrm{l})$. ACTH levels $-09 \cdot 15=190$ $\mathrm{pg} / \mathrm{ml} ; 23.00=65 \mathrm{pg} / \mathrm{ml}$ (normal range 10-80 $\mathrm{pg} / \mathrm{ml}$ ). Long Synacthen test $(1 \mathrm{mg})$ showed inadequate response with increase of cortisol from 500 to $580 \mathrm{mmol} / 1$ (normal $>1030 \mathrm{mmol} / \mathrm{l}$ ). Antibody screen (see Table 1).

Thus there was an inadequate adrenal response to Synacthen in both tests, and the morning ACTH level was raised. These results indicated some degree of adrenal hypofunction, the ACTH levels being in the range found in Addison's disease with maintenance of the normal diurnal rhythm.

Two of the other three brothers, aged 19 and 17 years, were investigated with short Synacthen tests and these were normal. Unfortunately, blood for antibody studies could not be obtained from them 
or their parents. However, they and the remaining brother who lived abroad were in good health and had had no significant previous illnesses.

\section{Discussion}

Thus, twin A presented with established Addison's disease and twin B, although symptomless, demonstrated biochemical evidence of hypoadrenalism. Antibodies to the adrenal cortex were found in both and the presence of these is associated with Addison's disease of auto-immune origin, being present in $65 \%$ of cases (Irvine and Barnes, 1975a). They were not found in any of sixty-two cases of tuberculous Addison's disease in this series and there is a very low incidence of these antibodies in the sera of either control subjects or patients with other organ-specific auto-immune disorders such as thyrotoxicosis, pernicious anaemia and hypothyroidism.

TABle 1. Antibody studies

\begin{tabular}{lcc}
\hline & Twin A & Twin B \\
\hline Adrenal cortex & + & + \\
Thyroid interstitial cell & - & + \\
Thyroglobulin & - & - \\
Smooth muscle & + & - \\
Parietal cell & - & - \\
Testis & - & - \\
Ovary & - & - \\
Placenta & - & - \\
\hline
\end{tabular}

TABLE 2. Blood groups and genotypes

\begin{tabular}{|c|c|c|c|c|}
\hline \multicolumn{3}{|c|}{ Twin A } & \multicolumn{2}{|c|}{ Twin B } \\
\hline \multicolumn{3}{|c|}{$\begin{array}{c}\text { Blood group } \\
\text { O Rhesus positive }\end{array}$} & \multicolumn{2}{|c|}{$\begin{array}{c}\text { Blood group } \\
\text { O Rhesus positive }\end{array}$} \\
\hline Genotype & $C^{w}$ & - & Genotype $\mathbf{C w}$ & - \\
\hline & $\mathrm{C}$ & + & $\mathrm{C}$ & + \\
\hline & $\mathrm{E}$ & + & $\mathrm{E}$ & + \\
\hline$\overline{\mathbf{c}}$ & $\bar{c}$ & + & $\overline{\mathbf{c}}$ & + \\
\hline e & e & + & e & + \\
\hline & $\mathbf{M}$ & + & $\mathbf{M}$ & + \\
\hline & $\mathbf{N}$ & - & $\mathbf{N}$ & - \\
\hline $\mathbf{S}$ & $\mathbf{S}$ & + & $\mathbf{S}$ & + \\
\hline $\bar{s}$ & $\bar{s}$ & + & $\overline{\mathbf{s}}$ & + \\
\hline & $\mathbf{K}$ & + & $\mathrm{K}$ & + \\
\hline & Fy & $a-$ & Fy & $a-$ \\
\hline & Fy & $\mathrm{b}+$ & Fy & $\mathrm{b}+$ \\
\hline & Jk & $\mathbf{a}+$ & $\mathbf{J k}$ & $a+$ \\
\hline & Le & $a-$ & Le & $a-$ \\
\hline & Le & $\mathrm{b}+$ & Le & $b+$ \\
\hline $\mathrm{p}$ & $\mathrm{p}$ & + & $\mathrm{p}$ & + \\
\hline
\end{tabular}

Auto-immune Addison's disease is associated with a markedly increased incidence of other organspecific auto-immune diseases such as thyrotoxicosis, hypothyroidism, hypoparathyroidism, diabetes mellitus and a particular type of premature gonadal failure, whereas there is no such connection with Addison's disease due to tuberculosis (Irvine and Barnes, 1975b). No evidence of any other active auto-immune disease was found in the present patients, but it was noted that one twin had thyroid interstitial cell antibodies present and the other had smooth muscle antibodies.

It has been said that all cases of familial Addison's disease have been shown to be idiopathic, i.e. not due to tuberculosis, infarction, sarcoidosis, carcinoma or irradiation, when post-mortem was performed (Dunlop, 1963) and three pairs of identical twins with Addison's disease have been described. In two of these reports, adrenal antibodies were not looked for and the diagnosis of an auto-immune aetiology was made by exclusion of other causes and by post-mortem evidence of adrenal cortical atrophy in one of the patients (Smith, Gough and Galpin, 1963; Heggarty, 1968). In the other pair, adrenal antibodies were demonstrated in one twin only, but both twins had idiopathic hypoparathyroidism as well (Irvine and Barnes, 1975c).

It has been suggested that familial idiopathic Addison's disease, alone and in association with idiopathic hypoparathyroidism, is due to an autosomal recessive form of inheritance (Wilkins, 1965) and this mode of transmission has also been postulated for Schmidt's syndrome-idiopathic Addison's disease and hypothyroidism (Frey, Vogt and Nerup, 1973; Carpenter et al., 1964). In a survey of 140 families containing patients with idiopathic Addison's disease and idiopathic hypoparathyroidism (Spinner, Blizzard and Childs, 1968), there was again evidence for an autosomal recessive mode of inheritance, particularly in those cases where the age of onset was below 20 years, but these results may have been distorted by the high incidence of consanguinous marriages when compared to the general population. Also the sex incidence of this condition differed from that of another series of idiopathic Addison's disease (Irvine and Barnes, 1975d).

In idiopathic Addison's disease and certain other auto-immune diseases, there is a disorder of immunological tolerance manifested by the development of organ-specific and also tissue-specific auto-antibodies, and inherited factors controlling the immune response are obviously of great importance. Although a specific form of inheritance has been proposed for certain syndromes involving idiopathic Addison's disease, a polygenic transmission would seem more likely in the majority of cases. 


\section{Acknowledgments}

We would like to thank Professor W. J. Irvine, Royal Infirmary, Edinburgh, for arranging the antibody screening, Dr Lesley Rees of St Bartholomew's Hospital for performing the ACTH estimations, and Mr J. Sherwood Smith, FIMLS, for defining the blood groups.

\section{References}

Carpenter, C.C.J., Soloman, N., Silverberg, S.G., BledSOE, T., NorthCutt, R.C., Klinenberg, J.R., BenNetT, I.L. \& HARVEY, A.M. (1964) Schmidt's syndrome. A review of the literature and a report of 15 new cases including 10 new cases of co-existent diabetes mellitus. Medicine. Baltimore, 43, 153.

Dunlop, D.M. (1963) 86 cases of Addison's disease. British Medical Journal, 2, 887.

Frey, H.M.M., Vogt, J.H. \& Nerup, J. (1973) Familial poly-endocrinopathy. Acta endocrinologica, 72, 401.
Heggarty, H. (1968) Addison's disease in identical twins. British Medical Journal, 1, 559.

IRvine, W.J. \& BARNES, E.W. (1975a) Clinical Immunology $\underset{c}{c}$ 3rd edn, p. 1311. Blackwell Scientific Publications, Oxford. $\Rightarrow$ IRvine, W.J. \& Barnes, E.W. (1975b) Clinical Immunology 3rd edn, p. 1315. Blackwell Scientific Publications, Oxford. IRvine, W.J. \& BARNES, E.W. (1975c) Clinical Immunology 3rd edn, p. 1343. Blackwell Scientific Publications, Oxford. IRVINE, W.J. \& BARNES, E.W. (1975d) Clinical Immunology 3rd edn, p. 1304. Blackwell Scientific Publications, Oxford. Smith, M.E., Gough, J. \& GalPIN, O.P. (1963) Addison's disease in identical twins. British Medical Journal, 2, 1316. SpinNer, M.W., Blizzard, R.M. \& Childs, B. (1968) Clinical and genetic heterogeneity in idiopathic Addison's disease and hypoparathyroidism. Journal of Clinical $\overrightarrow{\vec{H}}$ Endocrinology, 28, 795.

WILkINS, L. (1965) Diagnosis and Treatment of Endocrine Disorders in Childhood and Adolescence 3rd edn, p. 373. Thomas, Springfield, Illinois. 